\title{
Incorporating Professional Experience into Teaching
}

\section{Dr. Shannon L. Isovitsch Parks P.E., University of Pittsburgh, Johnstown}

Dr. Shannon Parks is a registered Professional Engineer with 20 years of broad-based experience in the water resources and environmental engineering fields. She holds a Bachelor of Science Degree in Civil Engineering from the Pennsylvania State University and a Masters of Science and doctoral degree in Civil \& Environmental Engineering from Carnegie Mellon University. She is currently teaching water resources and environmental engineering at University of Pittsburgh at Johnstown.

Prior to joining University of Pittsburgh at Johnstown, Dr. Parks' worked for over seven years at the Alcoa Technical Center focusing on development and commercialization of sustainable wastewater treatment and solid waste reuse technologies. She also served as a member of the Alcoa Foundation Board of Directors, providing environmental expertise to support the Foundation's focus areas of Environment, Empowerment, and Education, as well as her experience with science, technology, engineering, and mathematics (STEM) education for women. Prior to joining Alcoa in 2008, Dr. Parks worked for approximately seven years as a consultant to government agencies, municipalities, and industrial clients performing water resources engineering design and permitting. In addition to her corporate experience, Dr. Parks served as a Peace Corps Volunteer in Mali, West Africa, supporting a local Non-Governmental Organization on water sanitation projects.

\section{Dr. Laura J. Dietz, University of Pittsburgh, Johnstown}

Laura J. Dietz, Ph.D., trained as clinical and developmental psychologist at the University of Pittsburgh, completed a clinical internship at the Children's Memorial Hospital in Chicago, IL, and pursued postdoctoral training in clinical research at the University of Pittsburgh School of Medicine. She is an Assistant Professor of Psychology at the University of Pittsburgh at Johnstown. Dr. Dietz's research interests focus on early psychosocial interventions for mood disorders in youths and adapting developmentally appropriate interventions for depressed children and their families. She has been studying the effects of stress on health risk behavior in undergraduates, with a particularly focus on first-generation college students. 


\section{Incorporating professional experience into teaching}

\section{Introduction}

Most graduating engineers have the technical skills to succeed and find work. Good communication and teamwork skills set new graduates apart (Matusovich et al 2012) as these give potential employers an idea how the engineer will work in teams, communicate with clients, and interact with regulators. College professors that incorporate industry experience into their didactic activities through group projects, and peer and external feedback of oral presentations may build students' professional, 'soft skills', such as communication and teamwork, that can differentiate them to potential employers and provide them with the skills necessary for career advancement.

Bringing industry and research experience into the classroom by utilizing real world projects and guest speakers when discussing examples and applications of theory are recommended teaching practices for engineering professors (Loendorf 2004; Loendorf 2006; Lewis 2008; Banik 2016). The Accreditation Board of Engineering and Technology (ABET) recommends "real-world" engineering design, development, and operations, in addition to increasing formal instruction in both oral and written communication skills and teamwork skills, in order to produce graduates who are conversant with engineering ethics and the connections between technology and society (ABET 2017; Banik 2016). Teamwork skills are closely linked with communication, as it has been shown that students can improve their communication skills by participating in multidisciplinary teams (Garcia Lorca et al. 2015). Collaboration with industry in design projects, such as in the senior capstone design course, is one way in which universities are providing students with proper communication training. Universities are recommended to build upon these best practices by connecting with industry to understand the communication skills engineering managers are seeking in their new hires (Donnell et al 2011; Norback 2009). Bridging classroom didactics with industry experience allows the professor to share experiences with students that demonstrate the importance of good communication and teamwork skills.

Despite these recommendations, most engineering faculty do not proactively teach teamwork skills and the extent to which these identified teaching practices are integrated into engineering curriculums remain unclear (Matusovich et al 2012). This paper outlines how communication and teamwork skills and "real world" didactic experiences were integrated into a senior level undergraduate water/wastewater engineering course. The course integrated extensive oral and written communication practice, including writing, presenting, interviewing and networking with professionals, along with traditional engineering design skills. In addition, classroom lectures were supplemented with a combination of on-site industry tours, guest lecturers, peer review of oral presentations, and a team design project from an actual consulting firm project. Student satisfaction measures on the various classroom activities as well as industry professional and faculty measures on end of term student communication skills are presented. 
Methods

A senior level, undergraduate, civil engineering/technology elective on water and wastewater engineering was designed to integrate oral and written communication skills, teamwork skills, and industry experiences to the classroom curriculum. In addition to lectures, the course includes a weekly lab period, where the eight (8) enrolled students participated in a team design project that was provided by a local engineering design firm from one of their actual projects, and organized according to the Water Environment Foundations (WEF) national student design competition (WEF 2017). A copy of the design project requirements is included in Appendix A. The design firm's President and Co-founder presented two projects the first week of classes, and visited three (3) additional times to provide feedback on progress presentations and the final presentations. Progress presentations and reports were only $5 \%$ of the overall presentation and report grades, and were intended as a practice and learning opportunity to improve oral and written communication, as well as teamwork skills, throughout the course. During each progress presentation, students were asked to provide aloud constructive feedback to their peers on what was done well and what could be improved. This peer feedback was intended to provide students with oral communication practice that was impromptu and required critical thinking as well as diplomacy. The instructor and design firm President also provided this feedback. The final team presentations were given to an audience of other engineering faculty, the other students in the class, and a variety of industry professionals including the President of the design firm that provided the projects, and one of his engineers who worked on the project.

During the students' final team design project presentations, three (3) engineering faculty, three (3) industry professionals, and six (6) students provided feedback on the level of the team's oral communication skills compared to those of other young professionals. They were also asked to rate the team's oral communication via the Association of American Colleges and Universities Oral Communication VALUE Rubric. Students were also asked to rate their teammates via the Teamwork VALUE Rubric (Association of American Colleges and Universities 2010). The ratings were made on a scale of 1 to 4 , with 4 representing greatest communication or teamwork skill (i.e. capstone level), 2 and 3 being milestones, and 1 representing lowest communication or teamwork skill (i.e. benchmark). The ratings were completed by students from the class (100\% male), faculty ( $83 \%$ male) from the same institution representing civil and mechanical engineering, including the retired faculty member who previously taught the course, and industry professionals (100\% male) representing the design firm that provided the projects, as well as two additional design firms focused on environmental engineering and mining engineering.

In addition to the semester long design project, students participated in three (3) field trips to water and wastewater treatment plants, and three (3) guest speakers from the professor's network gained during their industry career visited the class. The speakers shared and discussed with the class real projects and situations dealing with manufacturing safety, wastewater engineering, sustainability, consulting, and environmental engineering in the mining industry. They also represented mentors and sponsors of the professor, and facilitated discussion on those aspects of an engineering career. These field trips and visits from guest speakers were intended to provide students with opportunities to connect classroom theory with "real world" practice, as well as provide them with another opportunity to practice oral communication skills via interviewing 
and networking with industry professionals.

At the end of the term, students were asked to what extent class activities such as the design project, peer review of presentations, guest speakers, the professor's examples from industry, and field trips contributed to their overall satisfaction with the course. Students were also asked to compare the degree this course utilized these activities compared to their other courses of a similar level (see Appendix, Student Survey). The eight (8) students enrolled in the class were asked to participate in the survey and six (6) completed the survey $(n=6)$.

For comparison, a sample of engineering professors with varying degrees of industry experience were also surveyed. They were asked to rate how often they integrated guest speakers, personal examples from their own experience in industry, and field trips in their classrooms.

Twenty-eight (28) professors were asked to participate in the survey, and 17 responded.

Results

Overall, 79\% of the three (3) engineering faculty and three (3) industry professionals who rated the students' oral presentations indicated the student teams as having oral communication skills better than other young professionals. Figure 1 illustrates that organization of presentations rated highest with all respondents, with $44 \%$ of all survey respondents rating the teams being at the highest skill level. Delivery was rated lowest overall, with $11 \%$ of all survey respondents rating teams as being at the highest skill level. Notably, industry professionals and students rated the teams higher on oral communication than professors (data not shown).

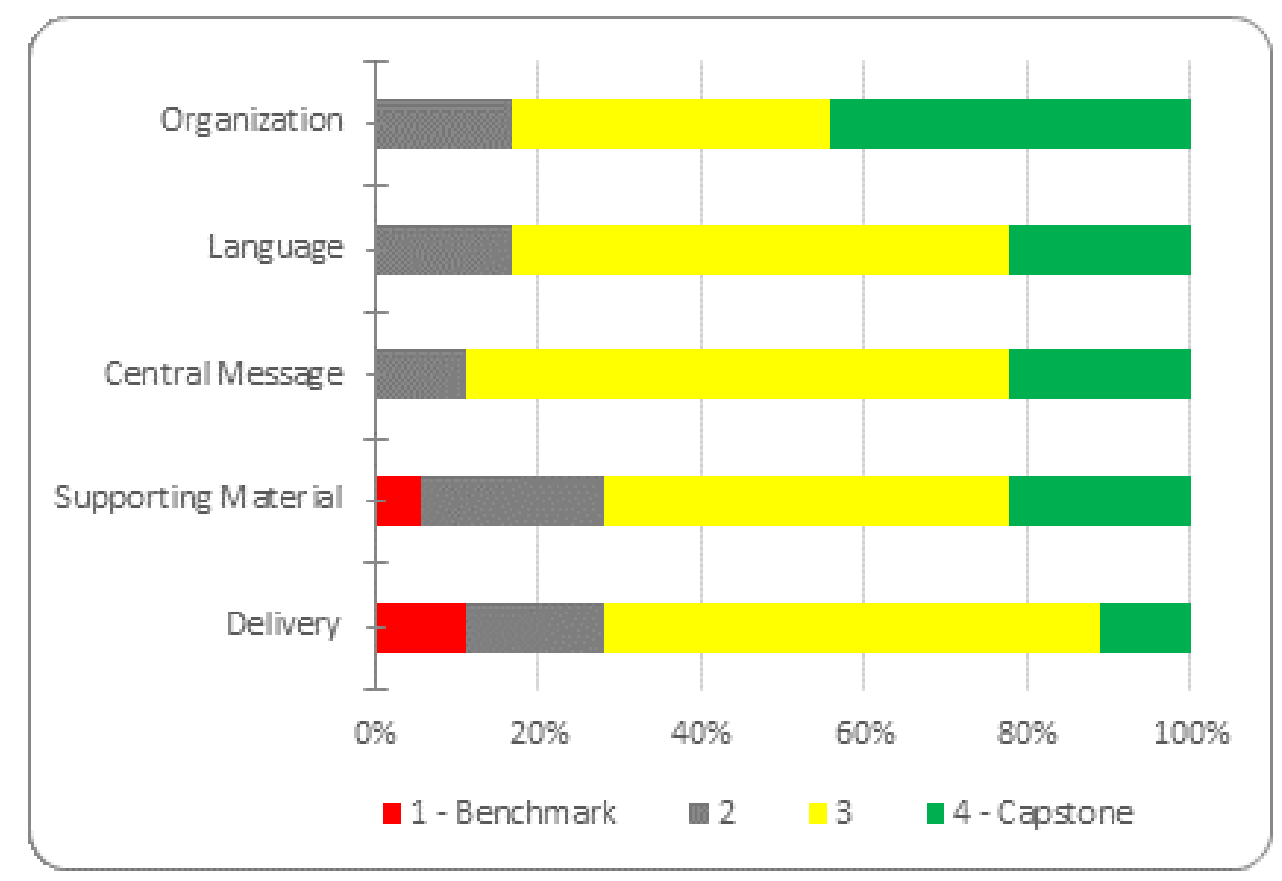

Figure 1: Oral Communication ratings 


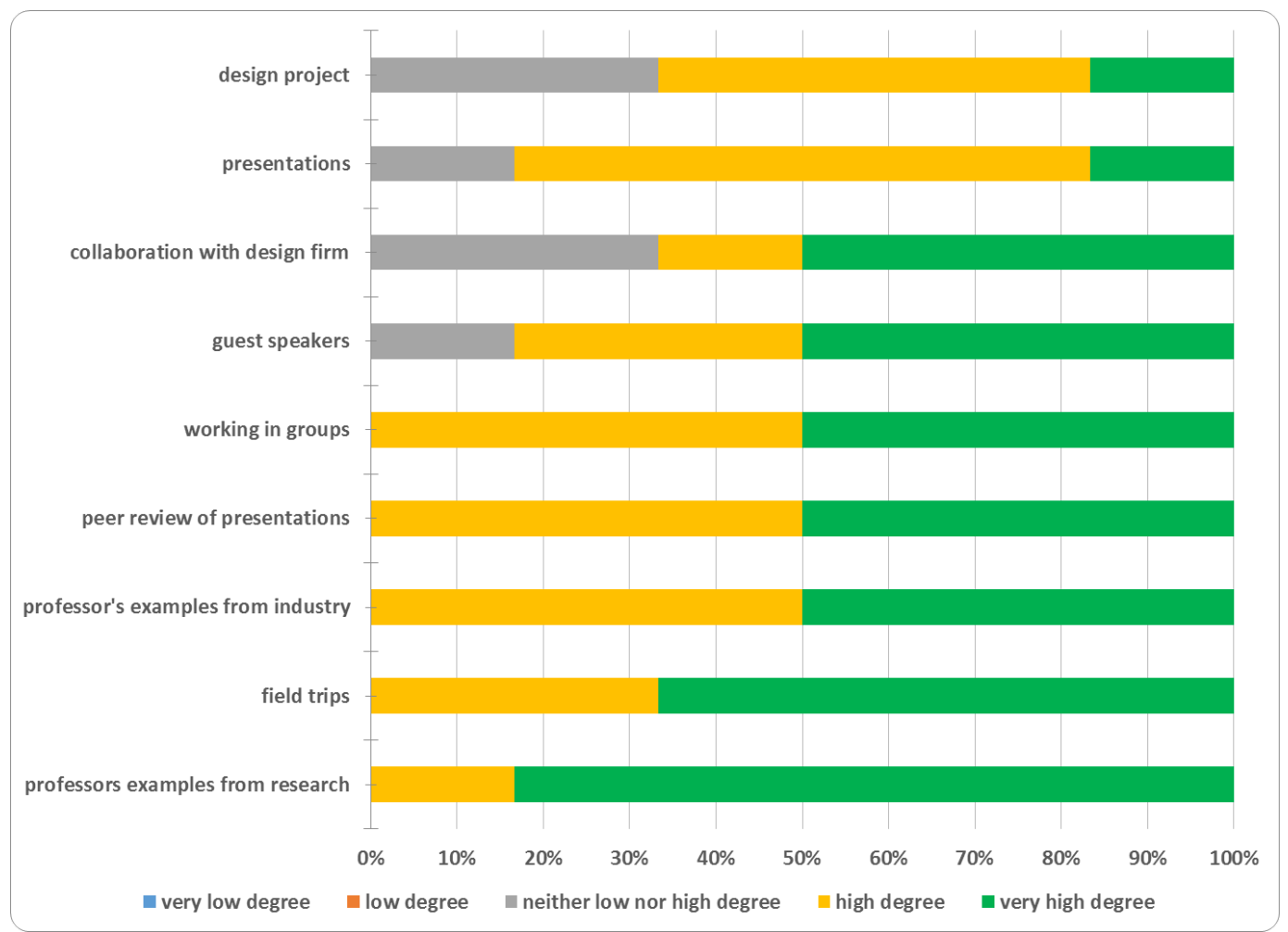

Figure 2: Extent activities contributed to student's course satisfaction

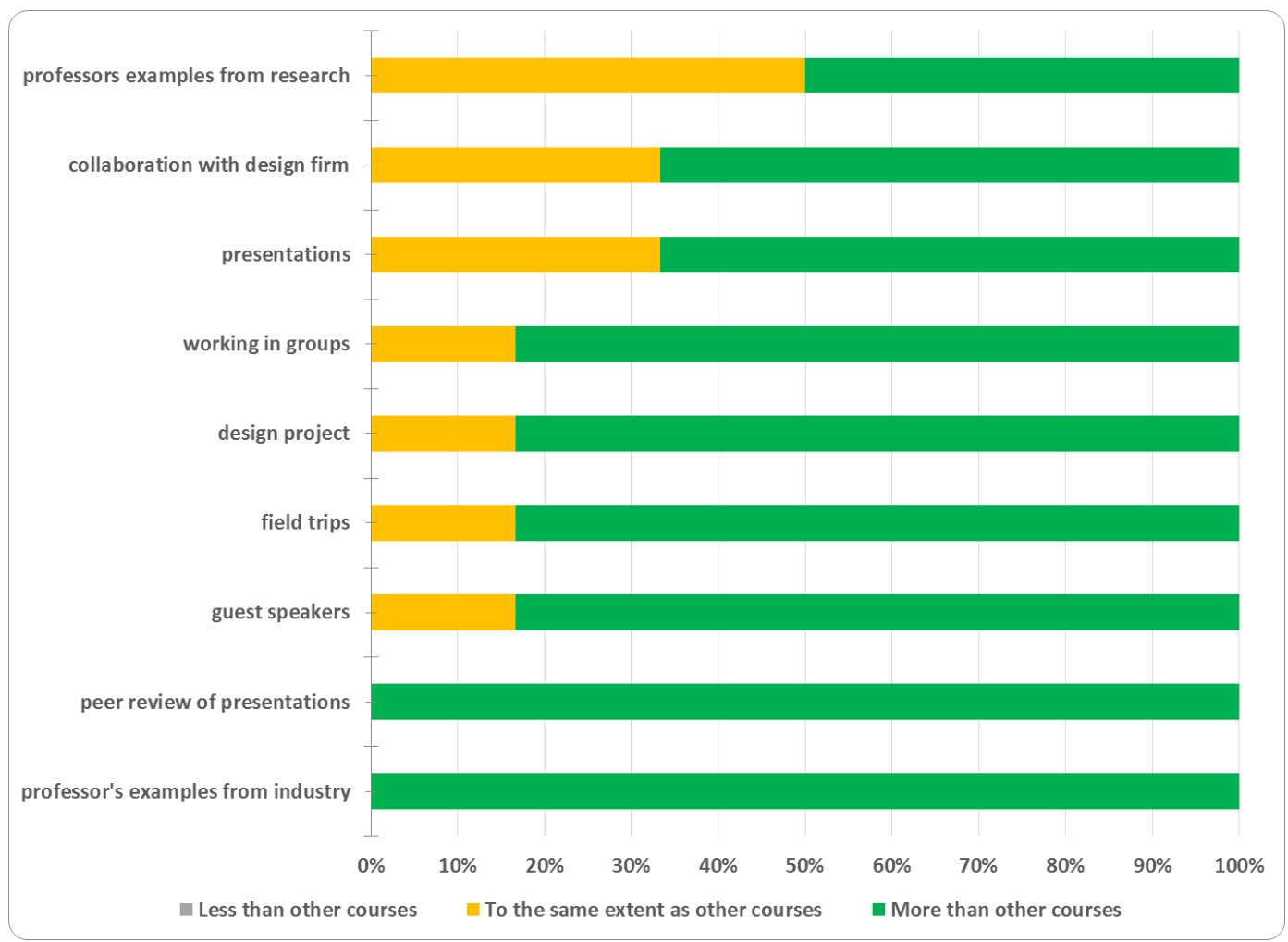

Figure 3: Extent activities were used compared to similar level courses 
Overall from the six (6) student responses received, the classroom activities surveyed added to student's course satisfaction while also setting the course apart. Figure 2 illustrates that all classroom activities surveyed were reported by at least $66 \%$ of students to add to course satisfaction by a high or very high degree, with the design project and associated collaboration with a local design firm scoring lowest with students. None of the activities were reported to bring satisfaction to a low or very low degree. Group work, peer review, field trips, and examples from industry and research, all were reported by $100 \%$ of students to provide a high or very high degree of course satisfaction. Figure 3 shows all classroom activities surveyed were reported by at least $50 \%$ of students to be utilized more than other similar level courses. Field trips and guest speakers were reported by $100 \%$ of students to be utilized more than other similar courses.

Of the 17 faculty responses received regarding use of similar classroom activities, two (12\%) are female and $88 \%$ are at teaching-focused institutions. Forty-seven percent $(47 \%)$ have worked in industry for at least 10 years prior to joining academia and $47 \%$ also work as a paid consultant outside of academia. Forty-seven percent (47\%) of respondents have been in their current position for at least 10 years, and 30\% have been in their current position for less than three (3) years. Fifty-six percent (56\%) of respondents have at least 10 years of experience teaching at the college level.

Figure 4 illustrates that more than $50 \%$ of faculty surveyed reported to never or only occasionally use guest speakers, field trips, or collaboration with a local design firm in their courses, which was consistent with student reports. These results indicate that the integration of these activities as was done in this course, is rare. Nonetheless, at least $50 \%$ of students surveyed reported that these activities added to course satisfaction to a very high degree. While the number of years of industry experience did not appear related to how often faculty utilized these activities, there was a trend for faculty with current consulting experience and those in academia for less than 10 years to employ peer review $(\mathrm{P}$-value $=0.074)$ and collaboration with local design firms $(\mathrm{P}$-value $=0.108)$ into their courses.

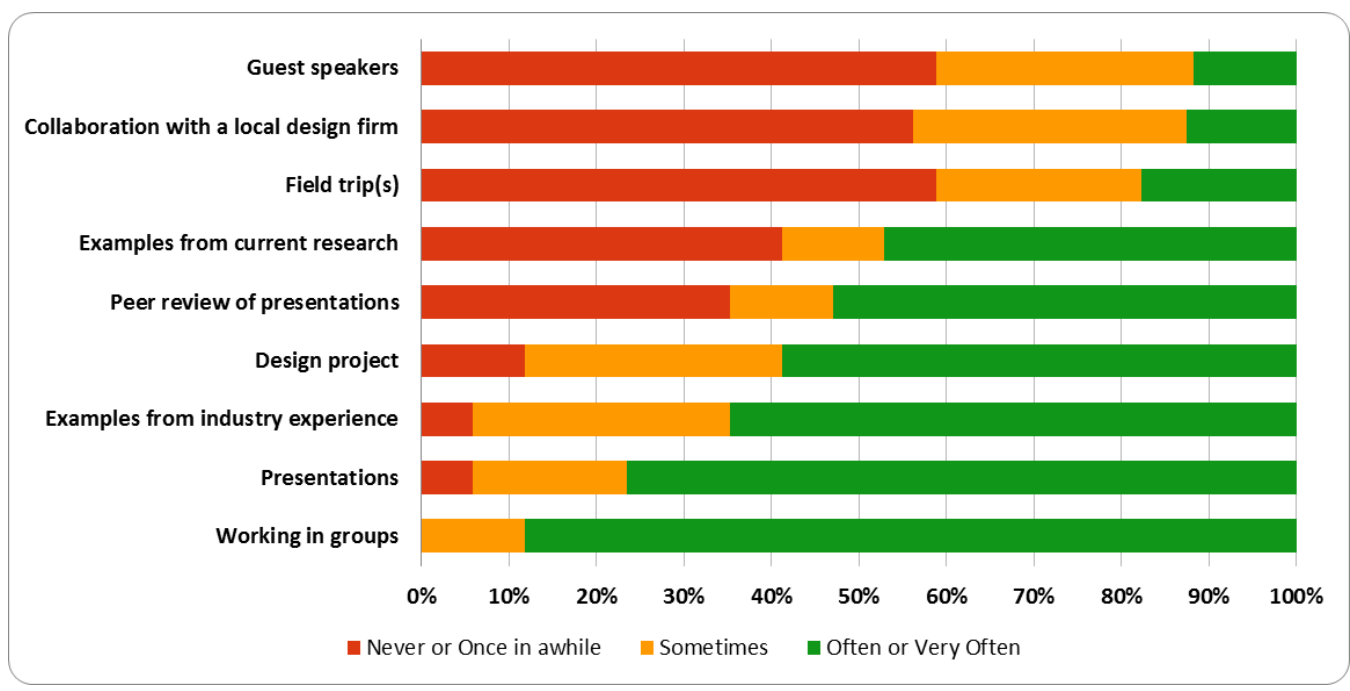

Figure 4: Extent activities are used by faculty 


\section{Discussion}

This paper examined the use of particular classroom activities thought to promote oral and written communication and teamwork skills while providing practical experience to prepare engineering students for the "real-world" of working in industry. The activities included group work, peer review, field trips, and examples from industry and research. While a baseline communication and teamwork skills survey was not performed, the faculty and industry professionals' assessment of the students' final presentations did indicate positive oral communication skills. Students indicated that the use of the activities included in the course is different compared to similar level courses, with at least half of the students saying that all of the activities were used more than their other similar level courses. These findings aligned with the faculty survey results that indicated most faculty rarely integrate guest speakers, field trips, or collaboration with a local design firm into the classroom.

Overall, results suggest that classroom activities such as group work, presentations, peer review, field trips, and guest speakers can add to students' satisfaction with a course while also building communication and teamwork skills. These particular activities may also enhance informal communication and networking skills, while providing students with a sense of what they can expect in their careers. Furthermore, many of these activities, particularly field trips, guest speakers, and collaboration with a local design firm, do not seem to be routinely integrated into college engineering curriculums despite ABET recommendations.

There were some challenges in integrating "real world" aspects of industry into classroom didactics. Teamwork was found to be a more difficult skill to assess. Only students were surveyed on this skill, as they were seen to be the best source of measuring their teammate's aptitude in this skill. Ninety-four percent (94\%) of students rated their teammates to be at capstone or just below in all subcategories of teamwork. Fostering a constructive team climate scored highest with $88 \%$, with facilitating the contributions of team members scoring lowest with $59 \%$. The design project also presented a challenge, in the amount of work required by students. This is most likely the reason for the lower satisfaction scores for this activity. Because the students were seniors, they were also working on their senior capstone design project simultaneously.

Some non-quantitative benefits were also found from these classroom activities. For instance, the relationship with the design firm resulted in a free 1-year professional society membership offered to each student. Also, the design firm President stated that some of the students' design ideas were directly integrated into the project at his company. He provided regular feedback not only on their design but also on how it would work in the real world with clients and regulators.

Training the next generation of engineers at colleges and universities requires that faculty provide opportunities for more applied teaching, facilitate connections between academia and industry, and build students' communication and teamwork skills. This study is a preliminary attempt to assess the acceptability and success of integrating "real world" experiences into the college classroom. Based on this work, it is recommended to incorporate a connection with professionals into the classroom such as through field trips, guest speakers, and design projects to build students communication and teamwork skills, and give them a sense of what to expect in 
the workplace. Future work includes examination of a larger sample size through continued use and assessment of classroom activities with a direct connection to the engineering industry, including pre- and post- course assessments. These pre- and post- course assessments will be comparable in form to ensure a reliable and quantifiable measure of gain. As the class is further refined and more students are exposed to these classroom activities, alumni can be surveyed to ascertain if they feel this particular class helped them to prepare for their engineering career. Further experiences and feedback from industry partners, students, and faculty will enable better understanding of the beneficial use of these classroom activities.

\section{References}

Association of American Colleges and Universities. Assessing Outcomes and Improving Achievement: Tips and tools for Using Rubrics, edited by Terrel L. Rhodes. Copyright 2010.

ABET. “CRITERIA FOR ACCREDITING ENGINEERING PROGRAMS, 2017 - 2018.” http://www.abet.org/accreditation/accreditation-criteria/criteria-for-accrediting-engineering-prog rams-2017-2018/. Accessed Jan. 21, 2017.

Banik, Gouranga. 2016. "Strategies and Techniques for New Tenure-track Faculty to Become Successful in Academia ," 2016 ASEE Annual Conference \& Exposition, New Orleans, Louisiana, https://peer.asee.org/25886, p.25886.

Donnell, Jeffrey A., Betsy M. Aller, Michael Alley, and April A. Kedrowicz. 2011. "Why industry says that engineering graduates have poor communication skills: What the literature says." American Society for Engineering Education.

Garcia Lorca, F., \& Ferguson, D. M., \& Condoor, S. S. 2015. "Reinforcing Communication Skills Through Participation in a Team-based Weekly Innovation Challenge," 2015 ASEE Annual Conference \& Exposition, Seattle, Washington. 10.18260/p.24664

Lewis, N. A. 2008. "The engineer as a professor: Bringing experience to the engineering classroom." ASEE Mid-Atlantic Section meeting, US Military Academy at West Point, NY

Loendorf, W. 2004. "Transitioning From Industry To Education: The First Year," 2004 ASEE Annual Conference, Salt Lake City, Utah. https://peer.asee.org/13033.

Loendorf, W. 2006. "Transitioning From Industry To Education: The Third Year," 2006 ASEE Annual Conference \& Exposition, Chicago, Illinois. https://peer.asee.org/178.

Matusovich, Holly M., Marie C. Paretti, Andrea M. Motto, and Kelly J. Cross. 2012. "Understanding faculty and student beliefs about teamwork \& communication skills." American Society for Engineering Education.

Norback, J. S., Leeds, E. M., and Forehand, G. A. 2009. Engineering Communication-Executive Perspectives on the Necessary Skills for Students. International Journal of Modern Engineering, vol. 10, no. 1, pp. 11-19

Water Environment Federation, 2017. "WEF Student Design Competition." http://wef.org/membership/students-and-young-professionals2/student-design/. Accessed January 30, 2017. 


\section{Appendix A \\ DESIGN PROJECT ASSIGNMENT}

\section{PROJECT CHOICES}

Choose one of the following 2 projects:

1) PROJECT1 water treatment plant was hit with the Corrective Action Plan (CAP) by the Department of Environmental Protection (DEP) because they exceeded their Barium level in their well water supply. Barium is a primary contaminant and must meet the new DEP limits that went from $4 \mathrm{mg} / \mathrm{l}$ to $2 \mathrm{mg} / \mathrm{l}$. The well is a secondary water supply with springs being the primary water source. Why is the Barium level elevated? What are the options to treat the elevated Barium level? What are the costs with each option?

2) PROJECT2 Municipal Authority's Sewage Treatment Plant (STP) was hit with the Corrective Action Plan (CAP) by the Department of Environmental Protection (PaDEP) because they exceeded their Organic loading. The Extended Aeration Plant's design flow is $140,000 \mathrm{gpd}$, the organic load is $238 \mathrm{lbs} /$ day, 550 customers, 4 restaurants, separate sewer system but still meets all effluent limits. The Organic load to the STP goes up $400 \mathrm{lbs} /$ day. Why is the organic load elevated? What are the options to treat the high organic load? What are the costs with each option?

\section{PROGRESS REPORTS}

Progress Reports and interim presentations are due as follows and as noted in the syllabus. Progress Reports count as $5 \%$ of the final Project Report grade; Interim presentations associated with the Progress Reports count as 5\% of the final Project Presentation grade. Teams not presenting are to provide constructive feedback and ask questions of the presenting team, as part of their participation grade. A PDF of progress reports shall be submitted via CourseWeb/Blackboard by midnight, on the following dates.

September 15: PROPOSAL PRESENTATIONS \& PROGRESS REPORT DUE

- team introduction and roles

- statement of design problem

- proposed alternatives to be evaluated ( 3 min; 5 max)

- 10 min presentation; 2 - 4 pages progress report

October 13: ALTERNATIVES EVALUATIONS PRESENTATIONS \& PROGRESS REPORT DUE

- Block Flow Diagram of each alternative (3 min; 5 max)

- +/- $50 \%$ cost estimate for each alternative

- pros and cons of each alternative

- 10 min presentation; $3-6$ pages progress report 
November 10: RECOMMENDED DESIGN SOLUTION PRESENTATIONS \& PROGRESS REPORT DUE

- Block Flow Diagram, with sizing and flows noted, on map of site

- +/- 30\% cost estimate

- Discussion on why recommended solution

- 10 min presentation; 8 - 12 pages progress report

\section{FINAL DELIVERABLE GUIDELINES}

The student project is based on the Water Environment Federation (WEF) Student Design Competition (http://www.wef.org/Publiclnformation/page.aspx?id=136), with the following adapted from the Design Competition Guidelines (2016):

Student teams will complete a written submission and an oral presentation.

a. Written: A design report complying with the requirements set forth in this document must accompany each entry. Final reports are due in a single PDF format file submitted via CourseWeb/Blackboard by Midnight, December 9, 2016.

b. Oral: Each team's presentation will be 20 minutes followed by up to a 10 minute question and answer period. Team presentations will be held to the 20 minute time limitation and will be not be permitted to continue beyond the limit. The presentation files shall be saved in PowerPoint format. Presentations will occur in class on Thursday, December 8, 2016.

c. Both written and oral presentations are subject to questioning during the question and answer period. Students in the audience are expected to participate in the questioning.

\section{DESIGN REPORT REQUIREMENTS}

The design report shall include, in the following order:

1. Cover Page - with project name, team name, and team members' names.

2. Table of Contents

3. Abstract - The abstract should include project name, team name, team members names, and a brief summary of the design, not to exceed 200 words.

5. Summary of Project Team Effort - Provide a 1 - 2 page summary of the project team effort, including:

- Each team member's name and role in the effort

- Names of any other individuals that assisted in the effort 
6. Project Description - Provide a description of the design problem, alternatives evaluation, and recommended design solution (not to exceed 20 pages), including the following information:

- Statement of design problem.

- Discussion of alternatives evaluation - Discussion should provide a clear description of the alternatives and evaluation technique.

- Description of recommended design solution - Discussion must cover the salient facts upon which the recommendation is made, present a clear recommendation of action, and provide bases for design. Relevant data should be presented in a clear manner. All elements shown on the judging form should be addressed, including economic analysis.

- Formatting to include a minimum of 0.75 inch margins on all sides; Calibri, Arial, or Times New Roman font with a minimum 11-point font size.

- Pages of the Project Description portion of the report shall be continuously numbered.

- Color diagrams, graphics, plots, and photographs may be included that reflect the unique features of the project. Each is to be identified with an appropriate descriptive caption. Graphics/photos included within the project description will count toward the 20-page limit.

7. Supporting Documentation - If needed, provide drawings, calculations, tables, vendor submittals, detailed cost estimates, and other voluminous documents, as appendices.

8. References/Acknowledgements - All references and resources used for this project shall be cited.

Teams shall develop their materials such that their complete analysis and design solution may be understood from the 20 pages of material provided in the Project Description.

Teams are encouraged to use a checklist to ensure all necessary documents are included in the design reports. Failure to ensure all documents are accounted for may result in a team penalty.

\section{JUDGING CRITERIA}

Grading will be based on the elements outlined below and in the example scoring sheets.

\section{DESIGN REPORT:}

a. Technical: Was the Project Description organized effectively with a Statement of Problem, appropriate background information, and a clear description of the alternatives evaluated? Was a continuous, logical sequence of steps taken to solve the design problem? Was the recommended solution feasible and appropriate to address the problem statement? Was a creative and innovative approach used?

Was knowledge of subject matter demonstrated? Was the design solution analyzed for economic feasibility? Were works cited and credit to resources and assistance 
correctly presented? Was the complete analysis and design solution presented clearly within the 20 page Project Description?

b. Presentation: Were visual aids (graphs, supporting info, pictures, etc.), presented clearly? Were correct grammar, correct spelling, and appropriate technical writing methods used? Was the formatting and organization presented in a logical manner?

\section{ORAL PRESENTATION:}

a. Content. Was technical subject matter relevant to design? To what extent was subject of interest to a technical audience? Was knowledge of subject and presentation content exhibited by team members? Was the work presented independent and original? Was credit given for source of material or contribution by others? Was there any novel approach to the solution?

b. Organization. Was sufficient background info. provided to introduce the audience to the subject? Were facts developed in logical and continuous sequence? Was there a definite conclusion and was it adequately based on facts or data presented?

c. Delivery and Effectiveness. Was appropriate volume used to reach all audience members? Were the words distinctly pronounced? Was personal appearance appropriate? Were there any distracting mannerisms? Was the manner of delivery (conversation, memorized, read from manuscript) satisfactory? If visual aids were used, how effectively were they used?

d. Discussion. Did the presentation evoke spontaneous questions? Did questions indicate the need for clarification of facts presented or were they merely of the type seeking additional information? How readily and with what self-assurance did the speaker answer questions? Did the answers indicate knowledge of subject beyond that disclosed in the original presentation? 
Name of Team:

Project Title:

Technical - 70 pts

1. Appropriate introduction, statement of problem, background information provided? (5 pts)

2. Continuous, logical sequence of steps to solution presented? (10 pts)

3. Was conclusion (design solution) based on logical steps presented? (10 pts)

4. Was design solution feasible and appropriate to address problem statement? (15 pts)

5. Were creativity and innovative approaches applied? (5 pts)

6. Was knowledge of subject matter demonstrated? (10 pts)

7. Were appropriate economic and feasibility analyses presented? (10 pts)

8. Were appropriate citations use to credit to resources? (5 pts)

TOTAL (70 pts)

Report Presentation - 30 pts

1. Were visual aids (graphs, supporting info, pictures, etc.) presented clearly? (10 pts)

2. Were correct grammar, correct spelling, and technical writing methods used? (10 pts)

3. Was formatting and organization of report presented in a logical manner? (10 pts)

TOTAL (30 pts)

GRAND TOTAL (100 pts)

COMMENTS: 


\section{EXAMPLE SCORING SHEET - PRESENTATION}

Name of Team:

Project Title:

Content - 45 pts

1. Presentation included sufficient depth of technical information (15 pts)

2. Technical information presented was relevant to design (10 pts)

3. Team displayed adequate knowledge of subject and presentation content (15 pts)

4. Recommended design solution was original and innovative (5 pts)

TOTAL (45 pts)

Organization - 20 pts

1. Sufficient background information was provided (5 pts)

2. Essential facts were developed in a logical and continuous sequence (10 pts)

3. Recommended design solution was based on facts and data presented (5 pts)

TOTAL (20 pts)

Delivery \& Effectiveness - 25 pts

1. Presentation and visual aides were clear, legible, and effective (10 pts)

2. Vocal delivery was appropriate (not memorized nor read directly; proper volume, distinct pronunciation, and appropriate vocabulary used) (10 pts)

3. Eye contact was made with judges and audience, no distracting mannerisms (5 pts)

TOTAL (25 pts)

Discussion - 10 pts

1. Answers to questions posed by judges were clear and technically correct (5 pts)

2. Answers indicated knowledge of subject beyond presented material (5 pts)

TOTAL (10 pts)

GRAND TOTAL (100 pts)

COMMENTS: 


\section{Appendix B - Surveys}

\section{Faculty Survey}

\begin{tabular}{|l|l|l|}
\hline Gender & Male & Female \\
\hline
\end{tabular}

Number of years in current position?

\begin{tabular}{|l|l|l|}
\hline Institution & Teaching-focused & Research-focused \\
\hline
\end{tabular}

Number of years teaching at college-level?

\begin{tabular}{|r|c|c|}
\hline $\begin{array}{l}\text { Have you worked in industry prior to your } \\
\text { current academic position? }\end{array}$ & Yes & No \\
\hline If so, for how many years? & \\
\hline
\end{tabular}

\begin{tabular}{|l|l|l|}
\hline $\begin{array}{l}\text { Are you a paid consultant with local } \\
\text { engineering firms? }\end{array}$ & Yes & No \\
\hline
\end{tabular}

\begin{tabular}{|l|l|l|l|l|l|}
\hline $\begin{array}{l}\text { In electives or upper-level classes, how } \\
\text { often do you incorporate the following } \\
\text { strategies into your teaching? }\end{array}$ & $\begin{array}{l}\text { Neve } \\
\mathrm{r}\end{array}$ & $\begin{array}{l}\text { Once in } \\
\text { awhile }\end{array}$ & $\begin{array}{l}\text { Sometime } \\
\mathrm{s}\end{array}$ & $\begin{array}{l}\text { Ofte } \\
\mathrm{n}\end{array}$ & $\begin{array}{l}\text { Very } \\
\text { Often }\end{array}$ \\
\hline Working in groups & & & & & \\
\hline Peer review of presentations & & & & & \\
\hline Presentations & & & & & \\
\hline Design project & & & & & \\
\hline Guest speakers & & & & & \\
\hline Examples from industry experience & & & & & \\
\hline Field trip(s) & & & & & \\
\hline Examples from current research & & & & & \\
\hline Collaboration with a local design firm & & & & \\
\hline
\end{tabular}




\section{Student Survey}

To what extent did each of the following contribute to your overall satisfaction with this course?

working in groups

peer review of presentations

presentations

design project

guest speakers

professor's examples from industry

field trips

professors examples from research collaboration with design firm

\begin{tabular}{|l|l|l|l|l|}
\hline $\begin{array}{l}\text { very } \\
\text { low } \\
\text { degree }\end{array}$ & $\begin{array}{l}\text { low } \\
\text { degree }\end{array}$ & $\begin{array}{l}\text { neither low } \\
\text { nor high } \\
\text { degree }\end{array}$ & $\begin{array}{l}\text { high } \\
\text { degree }\end{array}$ & $\begin{array}{l}\text { very } \\
\text { high } \\
\text { degree }\end{array}$ \\
\hline & & & & \\
\hline & & & & \\
\hline & & & & \\
\hline & & & & \\
\hline & & & & \\
\hline & & & & \\
\hline & & & & \\
\hline & & & & \\
\hline & & & & \\
\hline
\end{tabular}

Compared to other courses of a similar level, how often did this course utilize each of the following? working in groups

peer review of presentations

presentations

design project

guest speakers

professor's examples from industry

field trips

professors examples from research collaboration with design firm

\begin{tabular}{|l|l|l|l|l|}
\hline $\begin{array}{l}\text { very } \\
\text { low } \\
\text { degree }\end{array}$ & $\begin{array}{l}\text { low } \\
\text { degree }\end{array}$ & $\begin{array}{l}\text { neither low } \\
\text { nor high } \\
\text { degree }\end{array}$ & $\begin{array}{l}\text { high } \\
\text { degree }\end{array}$ & $\begin{array}{l}\text { very } \\
\text { high } \\
\text { degree }\end{array}$ \\
\hline & & & & \\
\hline & & & & \\
\hline & & & & \\
\hline & & & & \\
\hline & & & & \\
\hline & & & & \\
\hline & & & & \\
\hline & & & & \\
\hline & & & & \\
\hline
\end{tabular}

